\title{
Exclusion mapping of chromosomal regions which cross hybridise to FSHD1A associated markers in FSHD1B
}

\author{
J R Gilbert, M C Speer, J Stajich, R Clancy, K Lewis, H Qiu, L Yamaoka, A Kumar, \\ J Vance, C Stewart, M Rozear, A D Roses, M A Pericak-Vance
}

\begin{abstract}
Facioscapulohumeral muscular dystrophy (FHSD) is a genetically heterogeneous, autosomal dominant primary disease of muscle. The predominant form of FSHD, which has been designated FSHD1A, has been localised to the $4 \mathrm{q} 34$ region of human chromosome 4. The disease locus (loci) for the remaining FSHD families, which are not linked to chromosome 4 and have been designated FSHD1B, has not yet been identified.

The D4F104S1 marker which detects copies of a $3.2 \mathrm{~kb}$ tandem repeat $(\mathrm{D} 4 \mathrm{Z4})$ which contains several types of repetitive sequences, including Hox gene-like elements, has been shown to be closely linked to the chromosome 4 FHSD disease locus. The loss of an integral number of the $3 \cdot 2 \mathrm{~kb}$ tandem repeats has been associated with FSHD1A. When hybridised to chromosomal spreads these sequences cross hybridise with heterochromatin on acrocentric chromosomes and specific areas of human chromosomes 1,3 , and 10. Potentially these specific regions of cross hybridisation may be linked to FSHD1B. To examine this possibility we have carried out linkage studies in our largest FSHD1B family. In this paper we exclude these areas of specific cross hybridisation as disease loci for FSHD1B.
\end{abstract}

(f Med Genet 1995;32:770-773)

Division of Neurology, Department of Medicine, Duke

University Medical

Center, PO Box 2900,

Durham, North

Carolina 27710, USA

J R Gilbert

M C Speer

J Stajich

R Clancy

$\mathrm{K}$ Lewis

H Qiu

L Yamaoka

A Kumar

J Vance

C Stewart

$M$ Rozear

A D Roses

M A Pericak-Vance

Correspondence to: Dr Gilbert.

Received 1 March 199 Revised version accepted fo publication 9 May 1995
Facioscapulohumeral muscular dystrophy (FSHD) is a slowly progressive primary disease of muscle that is inherited as an autosomal dominant disorder, although isolated and autosomal recessive cases have been described. ${ }^{1}$ The incidence has been variously estimated at 1 to 10 cases per $100000 .^{2}$ There is considerable variability in the age of onset and severity, but the disease usually manifests itself in the second to third decade of life. ${ }^{34}$ Early symptoms usually involve facial or shoulder girdle weakness. FSHD is progressive in the majority of patients spreading to the abdominal, foot, arm, and pelvic girdle muscles. ${ }^{4}$ In addition to muscle involvement, retinal vasculopathy and high frequency hearing loss is observed in some FSHD patients. $^{56}$

Linkage of FSHD1A was originally established to the $4 \mathrm{q} 35$-qter region. ${ }^{78}$ Subsequently, the isolation of the $\mathrm{p} 13 \mathrm{E}-11$ probe
(D4F104S1), which was developed from a cosmid isolated using a Hox probe, and which detects de novo rearrangements on sporadic and familial FSHD blots, led to further fine mapping of the chromosome 4 FSHD region. ${ }^{910}$ Specifically, in 10 Dutch families an EcoRI fragment shorter than normally observed in controls was found to co-segregate with FSHD1A. This has led to the suggestion that a defect in a homeobox gene associated with muscle development may be the underlying defect in chromosome $4 \mathrm{q}$ linked FSHD. ${ }^{10}$

The FSHD associated rearrangements detected by the $\mathrm{p} 13 \mathrm{E}-11$ probe were subsequently shown to be associated with the loss of integral numbers of copies of a $3.2 \mathrm{~kb}$ tandem repeat (D4Z4), ${ }^{11} 12$ although a number of crossovers have been observed. ${ }^{13}$ Each monomer of the $3.2 \mathrm{~kb}$ repeat has been shown by sequencing to contain two homeoboxes and additional repetitive sequences such as LSau. ${ }^{12}$ In addition to the $4 \mathrm{q} 35$ region the repeat also cross hybridised to the heterochromatic pericentromeric and satellite bands on all of the acrocentric chromosomes and to specific areas on chromosome 1q12, 3p12, 10cen, and 10qter. ${ }^{12}$

Subsequent linkage studies have excluded several large FSHD families (FSHD1B) from the 4q FSHD1A region and shown FSHD to be a heterogeneous disorder. ${ }^{1415}$ Potential candidate regions for the localisation of the FSHD1B families are those chromosomal locations which cross hybridise to the $3.2 \mathrm{~kb}$ repeat closely associated with the chromosome 4 FSHD gene. In this report we investigate the possibility of linkage between FSHD1B and the repeat cross hybridising regions of human chromosomes 1,3 , and 10 .

\section{Methods}

FAMILY STUDIES

Duke FSHD family 689 was ascertained for study through the Muscular Dystrophy Association clinic at the Duke University Medical Center. Family 689 has been previously excluded from linkage to the $4 \mathrm{q} 35$ region. ${ }^{14}$ The clinical evaluation of this family has also been previously described. ${ }^{14}$ Briefly, the criteria of Lunt $e t a l^{16}$ were used in assigning clinical status and all family members used in this study were examined by a neurologist before assignment of affected status. Affected members of Duke family 689 met the clinical criteria for FSHD $^{16}$ 
including facial weakness, clavicular flattening, scapular winging, proximal muscle weakness, and myopathic changes on muscle biopsy without inflammatory or mitochondrial pathology. No obvious clinical differences between FSHD1A families and family 689 were observed. Blood was obtained at the time of clinical examination for DNA extraction and creatine kinase analysis from a total of 89 family members. For this study, a subset of the family including DNA samples on 32 affected subjects, 13 asymptomatic at risk subjects, and eight unrelated spouses was used.

\section{DNA ISOLATION, MARKERS, AND LINKAGE} ANALYSIS

DNA isolation and marker analysis were as previously described. ${ }^{14}$ Three markers were chosen for analysis in each of the four chromosomal areas that showed cross hybridisation to the $3.3 \mathrm{~kb}$ homeobox repeat sequence for a total of 12 markers. The 12 markers chosen were AMY2B, D1S185, and SPTA1 for chromosome 1q12 ${ }^{17}$; D3S1217, D3S1284, and D3S1215 for chromosome 3p12 ${ }^{18}$; D10S111, D10S174, and D10S196 for chromosome $10 \mathrm{cen}^{18}$; and D10S187, D10S216, and D10S212 for chromosome $10 \mathrm{q} 26{ }^{1819}$ Details regarding these markers, their heterozygosities, and their cytogenetic localisations are shown in table 1. These markers are all highly informative markers which flank the regions of homeobox cross hybridisation. The three chromosome 1 markers span a region of $44 \mathrm{cM}$ on 1q12; the three chromosome 3 markers $35.9 \mathrm{cM}$ on $3 \mathrm{p} 12$; and the chromosome 10 markers $40.8 \mathrm{cM}$ on $10 \mathrm{q} 26$ and $22.5 \mathrm{cM}$ on 10cen.

FSHD1B was analysed as an autosomal dominant disorder with age dependent penetrance. At risk subjects (asymptomatic offspring

Table 1 Markers and genetic maps used for investigation of candidate regions for FSHD family 689. Note that markers marked* were used for cytogenetic localisation only and were not genotyped in the pedigree

\begin{tabular}{|c|c|c|c|}
\hline Marker & Heterozygosity & $\begin{array}{l}\text { Genetic } \\
\text { distance (cM) }\end{array}$ & $\begin{array}{l}\text { Cytogenetic } \\
\text { localisation }\end{array}$ \\
\hline $\begin{array}{l}\text { Region 1q12 } \\
\text { AMY2B }\end{array}$ & 0.64 & \multirow{3}{*}{$\begin{array}{l}25 \\
19\end{array}$} & $1 \mathrm{p} 21$ \\
\hline D1S185 & $0 \cdot 49$ & & \\
\hline SPTA1 & 0.50 & & 1q21 \\
\hline $\begin{array}{l}\text { Region 3p12 } \\
\text { D3S1217 }\end{array}$ & 0.83 & \multirow{3}{*}{$\begin{array}{r}9 \cdot 2 \\
26 \cdot 7\end{array}$} & $3 \mathrm{p} 14.2-14.1$ \\
\hline D3S1284 & $0 \cdot 74$ & & \multirow[t]{2}{*}{ 3p13-p12 } \\
\hline D3S1215 & 0.78 & & \\
\hline $\begin{array}{l}\text { Region 10cen } \\
\text { D10S111/ } \\
\text { D10S174 }\end{array}$ & $\begin{array}{l}0.62 \\
0 \cdot 75\end{array}$ & \multirow{3}{*}{$\begin{array}{r}18 \cdot 3 \\
4 \cdot 2\end{array}$} & 10 pter-p11.2 \\
\hline RBP3* & & & \multirow[t]{2}{*}{$10 \mathrm{q} 11.2$} \\
\hline D10S196 & 0.79 & & \\
\hline $\begin{array}{l}\text { Region } 10 q 26 \\
\text { D1OS187 }\end{array}$ & $0 \cdot 82$ & & \multirow{3}{*}{$10 \mathrm{q} 26.1$} \\
\hline D10S12* & & $\begin{array}{r}14 \cdot 6 \\
4 \cdot 7\end{array}$ & \\
\hline $\begin{array}{l}\mathrm{D} 10 \mathrm{~S} 216 \\
\mathrm{D} 10 \mathrm{~S} 212\end{array}$ & $\begin{array}{l}0.60 \\
0.71\end{array}$ & $21 \cdot 5$ & \\
\hline
\end{tabular}

of FSHD affected patients) included in the analysis were assigned probabilities of carrying the FSHD gene on the basis of their age at the time of examination. The risk calculations were based on the data of Lunt et $a l^{16}$ with a maximum penetrance of $93 \%$ at the age of 20 and above. In addition, in a conservative approach, an affecteds only (low penetrance) analysis was performed which used genotypic information on all family members, but included phenotypic data with respect to disease status only on known affected patients. The frequency of the FSHD gene was set at 0.0001 for all linkage analyses, and the marker allele frequencies were computed from the family data usng the USERM13 version of the Mendel analysis program. $^{20}$

Simulation analysis of family 689 was performed to assess the power of this family to detect linkage. Analyses were carried out with the SIMLINK computer program ${ }^{2122}$ using both complete family information, with risk classes outlined above, and using affecteds only.

Two point linkage analysis was used in subprogram MLINK of the LINKAGE program package (version 5.15). The multipoint analyses were performed using the FASTLINK version $^{2324}$ of the LINKMAP subprogram of LINKAGE. ${ }^{25}$ Since the markers used are multiallele marker systems, the markers were recoded to three four allele systems for computational feasibility ${ }^{26}$ in the multipoint analysis. To ensure that the recoding of alleles did not alter the interpretation of results, the two point lod scores calculated using the full set of alleles were compared to those generated from the recoded alleles and only minor variations were seen between the two sets of results. Multipoint location scores were calculated as the $\log _{10}$ likelihood difference of FSHD1B placed at a relative position on a fixed map of loci, versus the unlinked state. Map distances were converted to recombination fractions allowing for a Kosambi level of interference.

Visual inspection of the genetic data for each of the four candidate regions was performed using the two most widely spaced markers flanking the region in affected family members only. A region was considered to be excluded when at least two affected family members had entirely different haplotypes inherited from their affected parent.

\section{Results}

Simulation studies using both an age adjusted and a low penetrance analysis verified that Duke 689 is capable of yielding significant lod scores $(Z>3.00)$ with $92 \%$ probability for

Table 2 Results from simulation analysis for FSHD1B family 689

\begin{tabular}{|c|c|c|c|c|}
\hline \multirow[b]{2}{*}{$\theta$} & \multicolumn{2}{|c|}{ Age adjusted } & \multicolumn{2}{|c|}{ Affecteds only } \\
\hline & $\begin{array}{l}\text { Mean } \\
\text { lod }\end{array}$ & $\underset{\text { lod }}{\operatorname{Max}}$ & $\begin{array}{l}\text { Mean } \\
\text { lod }\end{array}$ & $\begin{array}{l}\text { Max } \\
\text { lod }\end{array}$ \\
\hline $\begin{array}{l}0.00 \\
0 \cdot 05 \\
0 \cdot 10 \\
0 \cdot 15 \\
0 \cdot 20\end{array}$ & $\begin{array}{l}6 \cdot 15 \\
4 \cdot 39 \\
3 \cdot 13 \\
2 \cdot 22 \\
1 \cdot 45\end{array}$ & $\begin{array}{c}10 \cdot 2 \\
9 \cdot 79 \\
8 \cdot 30 \\
9 \cdot 12 \\
7 \cdot 15\end{array}$ & $\begin{array}{l}5 \cdot 26 \\
3 \cdot 72 \\
2 \cdot 63 \\
1 \cdot 86 \\
1 \cdot 26\end{array}$ & $\begin{array}{l}8 \cdot 34 \\
7 \cdot 98 \\
7 \cdot 91 \\
7 \cdot 13 \\
5 \cdot 74\end{array}$ \\
\hline
\end{tabular}


Chromosome 1

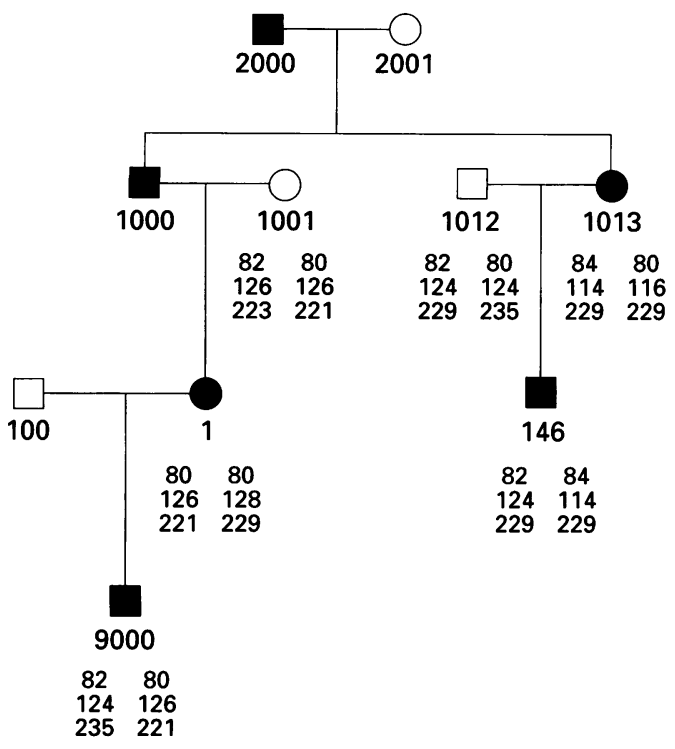

Chromosome 10cen

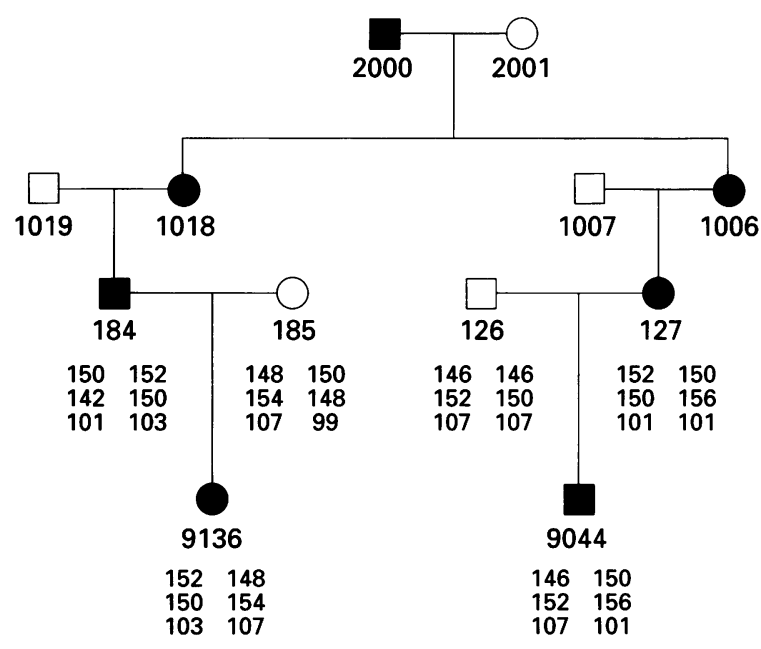

Chromosome 3

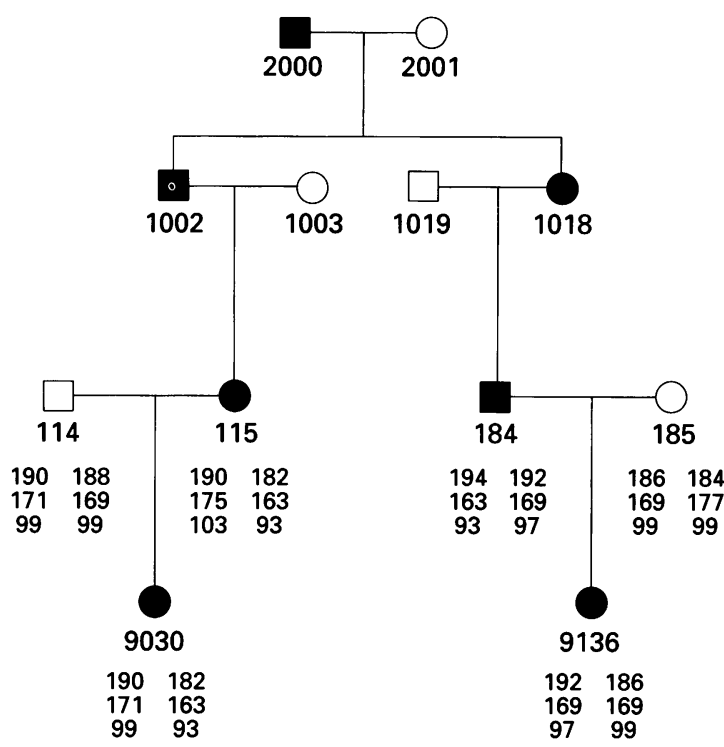

Chromosome 10q

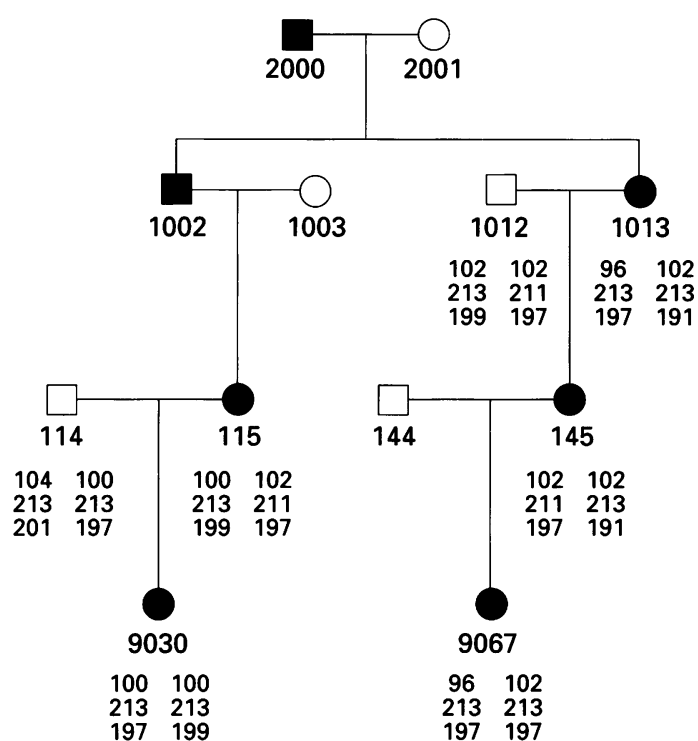

Haplotype analysis of representative portions of FSHD1B family 689 for each of the four chromosomal regions examined. Markers for chromosome 1 are $A M Y 2 B, D 1 S 185$, and SPTA1; for chromosome 3 D3S1217, D3S1284, and D3S1215; for chromosome 10cen D10S111/D10S174, RBP3, and D10S196; and for chromosome 10q D10S187, D10S216, and D10S212, top to bottom respectively, Recombinations between the FSHD1B and the chromosomal markers are clearly observed.

markers $5 \mathrm{cM}$ from the disease gene. The results can be seen in table 2 . Table 3 shows the two point lod scores in FSHD1B family 689 for both the age adjusted and affecteds only analysis for each of the three markers in the four chromosomal regions which cross hybridised with the $3 \cdot 2 \mathrm{~kb}$ repeats. The majority of the two point lod scores were negative for all members tested for both the age adjusted and affecteds only analysis. There was no evidence for significant linkage to any of the regions. The highest lod score realised was 0.85 for D10S216; the flanking markers to D10S216 (D10S187 and D10S212) were, however, neg- ative. Multipoint linkage analysis using both the age adjusted and low penetrance analyses excluded the regions between the most distant markers flanking the candidate region (that is, lod scores $<-2 \cdot 0$ ) for the $1 \mathrm{q}, 3 \mathrm{p}$, and 10 cen regions; the $10 \mathrm{q}$ multipoint lod scores were negative throughout the candidate interval, but did not reach the standard exclusion criteria of lod scores $<-2 \cdot 0$. Similarly, the low penetrance analysis allowed exclusion of the $1 \mathrm{q}$ and 10 cen areas, while the $3 p$ and $10 q$ candidate intervals had negative or slightly positive (peak lod score $=0.33$ in the $3 p$ region) lod scores within the interval. In addition, each of the four 
Table 3 Two point lod scores for markers in homeobox regions for FSHD1B family 689

\begin{tabular}{|c|c|c|c|c|c|c|c|}
\hline \multirow[b]{2}{*}{ Locus } & \multicolumn{7}{|c|}{ Recombination fraction $\left(\theta_{M}=\theta_{F}\right)$} \\
\hline & $0 \cdot 00$ & 0.05 & $0 \cdot 10$ & $0 \cdot 15$ & $0 \cdot 20$ & $0 \cdot 30$ & $0 \cdot 40$ \\
\hline $\begin{array}{l}\text { (A) Age adju } \\
\text { 1q12: } \\
\text { AMY2B } \\
\text { D1S185 } \\
\text { SPTA1 }\end{array}$ & $\begin{array}{l}-x \\
-x \\
-x\end{array}$ & $\begin{array}{l}-3.32 \\
-8.33 \\
-8.07\end{array}$ & $\begin{array}{l}-2 \cdot 04 \\
-4 \cdot 76 \\
-5 \cdot 44\end{array}$ & $\begin{array}{l}-1.40 \\
-2.86 \\
-3.95\end{array}$ & $\begin{array}{l}-1.04 \\
-1.69 \\
-2.95\end{array}$ & $\begin{array}{l}-0.62 \\
-0.47 \\
-1.59\end{array}$ & $\begin{array}{l}-0.31 \\
-0.10 \\
-0.66\end{array}$ \\
\hline $\begin{array}{l}\text { 3p12: } \\
\text { D3S1217 } \\
\text { D3S1284 } \\
\text { D3S1215 }\end{array}$ & $\begin{array}{l}-x \\
-x \\
-x\end{array}$ & $\begin{array}{l}-6.47 \\
-2.46 \\
-4.82\end{array}$ & $\begin{array}{l}-3.85 \\
-1.25 \\
-2.58\end{array}$ & $\begin{array}{l}-2 \cdot 33 \\
-0.60 \\
-1.44\end{array}$ & $\begin{array}{l}-1.35 \\
-0.23 \\
-0.76\end{array}$ & $\begin{array}{l}-0.26 \\
-0.10 \\
-0 \cdot 14\end{array}$ & $\begin{array}{r}0.12 \\
0.13 \\
-0.01\end{array}$ \\
\hline $\begin{array}{l}\text { 10cen: } \\
\text { D10S111 } \\
\text { D10S174 } \\
\text { D10S196 }\end{array}$ & $\begin{array}{l}-x \\
-x \\
-x\end{array}$ & $\begin{array}{l}-3.02 \\
-5.97 \\
-6.51\end{array}$ & $\begin{array}{l}-1.40 \\
-3.05 \\
-3.94\end{array}$ & $\begin{array}{l}-0.63 \\
-1.54 \\
-2.57\end{array}$ & $\begin{array}{l}-0.19 \\
-0.64 \\
-1.71\end{array}$ & $\begin{array}{l}-0.21 \\
-0.19 \\
-0.72\end{array}$ & $\begin{array}{l}0 \cdot 24 \\
0 \cdot 30 \\
0 \cdot 21\end{array}$ \\
\hline $\begin{array}{l}\text { 10q26: } \\
\text { D10S187 } \\
\text { D10S216 } \\
\text { D10S212 }\end{array}$ & $\begin{array}{l}-x \\
-x \\
-x\end{array}$ & $\begin{array}{r}-5.09 \\
0.72 \\
-3.01\end{array}$ & $\begin{array}{r}-2.71 \\
0.85 \\
-1.34\end{array}$ & $\begin{array}{r}-1.50 \\
0.84 \\
-0.50\end{array}$ & $\begin{array}{r}-0.80 \\
0.76 \\
-0.03\end{array}$ & $\begin{array}{r}-0.16 \\
0.52 \\
0.34\end{array}$ & $\begin{array}{r}-0.04 \\
0.25 \\
0.29\end{array}$ \\
\hline $\begin{array}{l}\text { (B) Affecteds } \\
\text { lq12: } \\
\text { AMY2B } \\
\text { D1S185 } \\
\text { SPTA1 }\end{array}$ & $\begin{array}{l}-\infty \\
-x \\
-x\end{array}$ & $\begin{array}{l}-3.50 \\
-6.58 \\
-6.61\end{array}$ & $\begin{array}{l}-2 \cdot 20 \\
-3 \cdot 48 \\
-4 \cdot 28\end{array}$ & $\begin{array}{l}-1.53 \\
-1.90 \\
-3.04\end{array}$ & $\begin{array}{l}-1 \cdot 12 \\
-0.97 \\
-2.23\end{array}$ & $\begin{array}{l}-0.61 \\
-0.11 \\
-1.18\end{array}$ & $\begin{array}{r}-0.28 \\
0.04 \\
-0.49\end{array}$ \\
\hline $\begin{array}{l}\text { 3p12: } \\
\text { D3S1217 } \\
\text { D3S1284 } \\
\text { D3S1215 }\end{array}$ & $\begin{array}{l}-x \\
-x \\
-x\end{array}$ & $\begin{array}{l}-5.07 \\
-1.69 \\
-4.11\end{array}$ & $\begin{array}{l}-2.91 \\
-0.65 \\
-2.08\end{array}$ & $\begin{array}{l}-1.69 \\
-0.15 \\
-1.07\end{array}$ & $\begin{array}{r}-0.93 \\
0.11 \\
-0.51\end{array}$ & $\begin{array}{r}-0.10 \\
0.25 \\
-0.02\end{array}$ & $\begin{array}{l}0.15 \\
0.17 \\
0.04\end{array}$ \\
\hline $\begin{array}{l}\text { 10cen: } \\
\text { D10S111 } \\
\text { D10S174 } \\
\text { D10S196 }\end{array}$ & $\begin{array}{l}-x \\
-x \\
-x\end{array}$ & $\begin{array}{l}-2.87 \\
-3.99 \\
-6.12\end{array}$ & $\begin{array}{l}-1.35 \\
-1.56 \\
-3.73\end{array}$ & $\begin{array}{l}-0.63 \\
-0.40 \\
-2.47\end{array}$ & $\begin{array}{r}-0.23 \\
0.23 \\
-1.69\end{array}$ & $\begin{array}{r}-0.13 \\
0.63 \\
-0.77\end{array}$ & $\begin{array}{r}0.19 \\
0.42 \\
-0.27\end{array}$ \\
\hline $\begin{array}{l}\text { 10q26: } \\
\text { D10S187 } \\
\text { D10S216 } \\
\text { D10S212 }\end{array}$ & $\begin{array}{l}-x \\
-x \\
-x\end{array}$ & $\begin{array}{l}-4.58 \\
-0.00 \\
-3.49\end{array}$ & $\begin{array}{r}-2.35 \\
0.21 \\
-1.70\end{array}$ & $\begin{array}{r}-1.25 \\
0.29 \\
-0.78\end{array}$ & $\begin{array}{r}-0.63 \\
0.31 \\
-0.25\end{array}$ & $\begin{array}{r}-0.10 \\
0.27 \\
0.20\end{array}$ & $\begin{array}{r}-0.03 \\
0.17 \\
0.22\end{array}$ \\
\hline
\end{tabular}

candidate regions was excluded by haplotype analysis in affected family members (figure).

\section{Discussion}

FSHD has recently been shown to be a heterogeneous disorder. This finding has important implications for both genetic counselling and the isolation of the 4q35 FSHD gene. Many FSHD families are often too small to allow definitive determination of whether they are chromosome 4 linked. While the development of the p13-11 probe has been an important diagnostic tool, the correlation between the loss of a number of $3.2 \mathrm{~kb}$ repeats and FSHD1A is not absolute. ${ }^{13}$ In addition, interpretation of the results obtained from the use of p13-11 is often quite difficult. The linkage and identification of the second FSHD locus and potentially additional loci which may cause the disease is of great importance for FSHD diagnosis, treatment, and mutation analysis.

One obvious location for a second locus would be those distinct areas of chromosome $1 \mathrm{q}, 3 \mathrm{p}, 10 \mathrm{cen}$, and $10 \mathrm{q}$ which cross hybridise with the homeobox repeat. In this study we have examined four of these chromosomal areas in a large, confirmed non-chromosome 4 linked FSHD family. Using both linkage analysis and haplotype analysis these four regions have been excluded as the FSHD locus in family 689 in their entirety.

The authors wish to thank the family members, Carol Haynes, Helen Harbett, and Debra Gross for data entry and data management, and Edward Hansen and Timothy Tucker for DNA handling and extraction. This research was funded through the support of the Muscular Dystrophy Association.

1 Moser H, Wiesmann U, Richterlich R, Rossi E. Progressive Muskeldystrophie. Schweiz Med Wochenschr 1966;96:16974.

2 Morton NE, Chung CS. Formal genetics of muscular dystrophy. Am f Hum Genet 1960;11:360-79.

3 Walton JN, Gardner-Medwin D. Progressive muscular dystrophies and the myotonic disorders. In: Walton JN, ed Disorders of voluntary muscle. Edinburgh: Churchill Livingstone, 1981:502-5.

4 Dubowitz V. Facioscapulohumeral dystrophy. In: Muscle biopsy: a practical approach. London: Bailliere-Tindall, 1985.

5 Fitzsimons RB, Gurmin EB, Bird AC. Retinal vascular abnormalities in facioscapulohumeral muscular dystrophy. Brain 1987;100:631-48.

6 Voit T, Lamprecht A, Lenard HG, Goebel HH. Hearing loss in facioscapulohumeral dystrophy. Eur F Pediatr 1986; 145:280-5.

7 Wijmenga C, Frants RR, Brouwer OF, Moerer P, Weber JL, Padberg GW. Location of facioscapulohumeral muscular dystrophy gene on chromosome 4. Lancet 1990;336:651-

8 wijine

jmenga C, Padberg GW, Moerer P, et al. Mapping of the facioscapulohumeral muscular dystrophy gene to chromosome 4q35-qter by multipoint linkage analysis and in situ hybridization. Genomics 1991:9:570-5.

9 Wijmenga C, Hewitt JE, Sandkuijl LA, et al. Chromosome $4 \mathrm{q}$ DNA rearrangements associated with facioscapulohumeral muscular dystrophy. Nature Genet 1992; 2:26-30.

10 Fischbeck KH, Garbern JY. Facioscapulohumeral muscula dystrophy defect identified. Nature Genet 1992;2:3-4.

11 van Deutekom JCT, Wijmenga C, van Tienhoven EAE, et al. FSHD associated DNA rearrangements are due to deletions of integral copies of a $3.2 \mathrm{~kb}$ tandemly repeated unit. Hum Mol Genet 1993;2:2037-42.

12 Winokur S, Bengtsson U, Feddersen J, et al. The DNA rearrangement associated with facioscapulohumeral muscular dystrophy involves a heterochromatin-associated repetitive element: implications for a role of chromatin petitive element: implications for a role of chromatin
structure in the pathogenesis of the disease. Chrom Res structure in the

13 Weiffenbach B, Dubois J, Storvick D, et al. Mapping the facioscapulohumeral muscular dystrophy gene is complicated by chromosome $4 \mathrm{q} 35$ recombination events. $\mathrm{Na}$ ture Genet 1993;4:165-9.

14 Gilbert JR, Stajich JM, Wall S, et al. Evidence for heterogeneity in facioscapulohumeral muscular dystrophy (FHSD). Am f Hum Genet 1993;53:401-8.

15 Iqbal Z, Roper HH, Pericak-Vance MA, et al. Genetic heterogeneity in facioscapulohumeral disease. Am $\mathcal{F} \mathrm{Hum}$ Genet Suppl 1992;51:A191,750.

16 Lunt PW, Noades JG, Upadhyaya M, Sarfarazi M, Harper PS. Evidence against the location of the gene for facioscapulohumeral muscular dystrophy on the distal long arm of chromosome 14.7 Neurol Sci 1988;88:287-92.

17 Engelstein M, Hudson TJ, Lane JM, et al. A PCR-based linkage map of human chromosome 1. Genomics 1993;15: 251-8.

18 Cooperative Human Linkage Center (CHLC). A comprehensive human linkage map with centimorgan density. Science 1994;265:2049-54.

$19 \mathrm{HIH} / \mathrm{CEPH}$ collaborative mapping group. A comprehensive genetic linkage map of the main genome. Science 1992;
258:67-86.

20 Boehnke $M$. Allele frequency estimation from data on relatives. Am $\mathcal{F}$ Hum Genet 1991;49:242-4.

21 Boehnke M. Estimating the power of a proposed linkage study: a practical computer simulation approach. $A m \mathcal{F}$ Hum Genet 1986;47:218-27.

22 Ploughman LM, Boehnke M. Estimating the power of a proposed linkage study for a complex genetic trait. $A m$ Hum Genet 1989;44:543-51.

23 Schaffer AA, Gupta SK, Shriram K, Cottingham RW. Avoiding recomputation in linkage analysis. Hum Hered 1994; 44:225-37.

24 Cottingham RW, Idury RM, Schaffer AA. Faster sequential genetic linkage computations. Am $\mathcal{F}$ Hum Genet 1993;53. $52-63$

25 Lathrop GM, Lalouel JM, Julier C, Ott J. Strategies for multilocus linkage analysis in humans. Proc Natl Acad Sci USA 1984;81:3443-6.

$26 \mathrm{Ott} \mathrm{J}$. Computer simulation methods in human linkeage analysis. Proc Natl Acad Sci USA 1989;86:4175-8. 